\title{
Bigger is not always better: The consequences of High-flow hemodialysis arterial-venous fistula (Mega fistula)
}

\author{
Awad Magbri*, Shaukar Rashid and Balhinder Brar \\ Toledo Vascular Access Center, Toledo OH, USA
}

\section{Case history}

The patient is 45 year-old African American female on maintenance hemodialysis through an arterial-venous fistula (AVF) in the left upper arm for the last 3 years. She came to Toledo Vascular Access Center (TVAC) with infiltration and low urea reduction ratio (URR) despite high blood flow through the fistula. On examination, she is well nourished middle-aged female with blood pressure of 146/90 $\mathrm{mm} \mathrm{Hg}$, and a heart rate of 102 beats per minute. The ECG tracing showed trigeminy but otherwise sinus rhythm. Doppler ultra-sound of the shunt showed that she has left upper arm brachial-cephalic AVF with fistula diameter of $2.5 \mathrm{~cm}$ near its origin and located at 2 $\mathrm{mm}$ depth from the skin surface. The Doppler ultra-sound showed that the flow through the fistula is $3300 \mathrm{ml} / \mathrm{min}$. The Nicoladoni-Branham maneuver was positive (decrease in pulse rate from 104 to $77 \mathrm{BPM}$ and rise in the blood pressure to $157 / 100 \mathrm{mmHg}$ ) on exerting sustained pressure on the arterial anastomosis of the AVF for 60 seconds. This sign indicates that the AVF is producing cardiac volume overload [1]. Echocardiography revealed left ventricular dilation and hypertrophy along with an estimated cardiac output of $7.3 \mathrm{~L} / \mathrm{min}$. She underwent a fistulogram at the TVAC which showed a mega-fistula with relative stenosis in the outflow vein at the cephalic arch levels and evidence of pulmonary hypertension manifested by reflux of the contrast into the internal jugular venous system on systole. She has cardiomegaly but clear lung fields.

\section{Discussion}

We all know the ideal hemodialysis access is AVF which should have just enough blood flow to maximize dialysis efficiency and at the same time prevent thrombosis. The arbitrary guideline for blood flow in a typical hemodialysis access is $(600-1500 \mathrm{ml} / \mathrm{min})$; a low blood flow in the access is considered at $(\leq 600 \mathrm{ml} / \mathrm{min})$ and a high flow in the access if it exceeds (1500-400 $\mathrm{ml} / \mathrm{min})$ [2]. Arterial-venous fistula is plagued with steal syndrome (SS), aneurysmal dilation with inherited consequences of rupture and repeated episodes of high output heart failure with enlargement of the heart chambers and eventually dilated cardiomyopathy and pulmonary hypertensions [2-4].

High output cardiac failure is well known phenomenon of high flow fistula (mega-fistula) in patients with end-stage renal disease on hemodialysis (ESRD/HD) [5,6]. On the other hand, young dialysis patients with upper arm AVF can tolerate high flow through the fistula up to $4 \mathrm{~L} / \mathrm{min}$ without any ill effects even though these measurements of access flow is usually performed at rest. We know that cardiac output can double or triple during exercise and therefore the flow through the access can reach as much as $12 \mathrm{~L} / \mathrm{min}$, this increase in cardiac output, undoubtedly, causes ample exertion on the heart and eventually leads to cardiac overload (1) with pulmonary hypertension which is a common occurrence in patients with ESRD/HD $[5,6]$.

\author{
The proposed criteria for the definition of high-outflow AVF \\ (HOFAVF) are $[7,8]$;
}

- Blood flow through the AVF $>2.2 \mathrm{~L} / \mathrm{min}$

- Hypertrophied feeding artery with increased blood flow

- Cardiopulmonary recirculation $>20 \%$

- High output cardiac failure with cardiac output $>4-8 \mathrm{~L} / \mathrm{min}$

- Cardiac index >3 (ratio of cardiac output to body surface area)

Dilatation and enlargement of the draining vein of the fistula, along with a flow of $>2000 \mathrm{ml} / \mathrm{min}$, and increased access pressure are considered features of mega-fistula. For the development of large aneurysmal dilation of the fistula, 2 factors are required; a) weakening of the fistula wall by repeated cannulation during dialysis treatments. B) Increased access pressure due to relative or absolute stenosis in the outflow venous system and mismatching of inflow and outflow blood through the fistula with inflow $>$ outflow. This mismatch will eventually lead to build up of the access pressure and together with weakened access wall of the fistula will lead to aneurysmal dilatation and mega-fistula.

After creation of an AVF there is immediate decrease in the peripheral vascular resistance which is compensated by an increased cardiac output. Large AVF is associated with various deleterious changes including subendocardial ischemia, diastolic dysfunction, congestive heart failure, pulmonary hypertension, and finally dilated cardiomyopathy. The hemodynamic effects of AVF can results in activation of the sympathetic nervous system with increase heart rate, stroke volume, and contractility of the heart. These changes lead to left ventricular hypertrophy and eventually to dilation of the left ventricle. Coronary perfusion on high-flow fistula cannot match the work of the heart and results in subendocardial ischemia and fibrosis in the long term [4,9-12].

One wonder why patients with high-flow fistula sometimes presented with decreased clearance and low urea reduction ratio (URR). High-flow AVF can presented with reduction in URR as the main complaints on hemodialysis. To understand this phenomenon, one must understand the cardio-pulmonary recirculation [13]. During dialysis treatment, fistula flow returns a high percentage of cleaned blood to the right heart and pulmonary circulation. With the next

Correspondence to: Awad Magbri, Toledo Vascular Access Center, Toledo OH, USA, Tel: 4122715106; E-mail: elmagbri@hotmail.com

Received: March 02, 2018; Accepted: March 22, 2018; Published: March 27, 2018 
contraction of the heart, a percentage of the freshly cleaned blood will be returned immediately to the fistula. This cleaned blood will be entering the fistula and cleaned again. The portion of blood that entered the fistula goes without significant urea clearance (already cleaned of urea). This portion of cleaned blood is called recirculating blood and amount to $30 \%$ of the cardiac stroke volume in an upper arm fistula with a blood flow of $>2 \mathrm{~L} / \mathrm{min}$. Therefore, a high fistula flow will result in low dialysis clearance and low URR [12-15]. The low URR is a testament to the presence of high-flow fistula in dialysis patients. A simple test can help determine if a high-flow fistula is a stressor to the heart or not. The Nicoladoni-Branham test can be done at the bed side with pressure at the arterial anastomosis for 30-60 seconds to occlude the blood flow to the fistula. The response to this maneuver is decrease in the pulse rate and increase in the blood pressure, which is due to normalization of the circulating blood flow by occluding the fistula. Release of the pressure at the arterial anastomosis will result in increasing the heart rate within 15 seconds [1].

Weakening of the wall of the fistula from repeated cannulation and high pressure inside the fistula will results in the development of aneurysms which may rupture with a calamitous consequence [16]. Decreasing the flow through the high-flow fistula will diminish the pressure inside the fistula and reduce the wall stress. This process can be achieved by Minimally Invasive Limited Ligation Endoluminalassisted Revision (MILLER) banding. This simple surgical procedure which can be done in an out-patient setting would decrease the pressure and wall stress inside the fistula by $60-80 \%$ and arrests the growth of the aneurysms [17]. Upper arm fistulas \{brachial-cephalic AVF (BCAVF) and brachial-basilic (BBAVF)\} can develop cephalic arch stenosis (CAS) and central venous stenosis (CVS) respectively, due to inflowoutflow mismatch [18-20]. Cephalic arch stenosis accounts for $19.5 \%$ to $77 \%$ of all BCAVF failures $(21,22)$. Brachial-cephalic AVF is 37 times more likely to have CAS than radial-cephalic AVF (RCAVF) [22,23].

BBAVF is also associated with high incidence of CVS compared to RCAVF [24]. These relative stenoses in the fistulas (CAS and CVS) are due to inflow-outflow blood mismatching. The high flow in the fistula may be presented with arm swelling, cyanosis, and collateral vein formation on the upper arm and chest. Previous central venous catheters and cardiac device wires can exacerbate CVS $[25,26]$. The inflow-outflow mismatch with high inflow compared to outflow through the fistula results in building up of the pressure inside the fistula which can be manifested as high venous pressure or prolonged bleeding after the dialysis session. Applying a tourniquet around the inflow during dialysis will decrease the inflow through the mega fistula and can improve the clearance while waiting for MILLER banding procedure for permanent solution. Flow reduction within the fistula using MILLER banding procedure or surgical Revision Using Distal Inflow (RUDI) technique can mitigate the symptoms of mega-fistula and avert the heart and lung complications caused by high-blood flow through these conduits.

In conclusion, the case under discussion, showed the presence of relative CAS, pulmonary hypertension, and cardiomegaly with features of congestive heart failure. These changes demand MILLER banding or RUDI procedure instead of angioplasty of the cephalic arch which can exacerbate post-dialysis bleeding and reduced clearance.

High flow AVF with high venous pressure, stenosis of the outflow tracts (CAS or CVS) and low dialysis clearance with low URR needs flow reduction rather than angioplasty of the outflow tract to tip the balance of inflow-outflow to the normal ratio.

\section{Funding}

The authors have no financial disclosure.

\section{References}

1. Velez-Roa S, Neubauer J, Wissing M, Porta A, Somers VK, et al. (2004) Acute arteriovenous fistula occlusion decreases sympathetic activity and improves baroreflex control in kidney transplant patients. Nephrol Dial Transplant 19: 1606-1612. [Crossref]

2. Bourquelot P, Stolba J (2001) Surgery of vascular accessfor hemodialysis and central venous stenosis. Nephrologie 22: 491-494.

3. Goel N, Miller GA, Jotwani MC, Licht J, Schur I, et al. (2006) Minimally Invasive Limited Ligation Endoluminal-assisted Revision (MILLER) for treatment of dialysis access-associated steal syndrome. Kidney Int 70: 765-770. [Crossref]

4. Engelberts I, Tordoir JH, Boon ES, Schreij G (1995) High-output cardiac failure due to excessive shunting in a hemodialysis access fistula: an easy overlooked diagnosis. $\mathrm{Am}$ J Nephrol 15: 323-326. [Crossref]

5. Iwashima Y, Horio T, Takami Y, Inenaga T, Nishikimi T, et al. (2002) Effects of the creation of arteriovenous fistula for hemodialysis on cardiac function and natriuretic peptide levels in CRF. Am J Kidney Dis 40: 974-982. [Crossref]

6. Bailey WB, Talley JD (2000) High-output cardiac failure related to hemodialysis arteriovenous fistula. J Ark Med Soc 96: 340-341. [Crossref]

7. Miller GA, Hwang WW (2012) Challenges and management of high-flow arteriovenous fistulae. Semin Nephrol 32: 545-550. [Crossref]

8. Mega Fistula. (Last accessed on 2018 Feb 23) Avaiable from: http://www.media nephrology.edu.au/anzsin/20018.

9. Amerling R, Ronco C, Kuhlmann M, Winchester JF (2011) Arteriovenous fistula toxicity. Blood Purif 31: 113-120. [Crossref]

10. von Bibra H, Castro L, Autenrieth G, McLeod A, Gurland HJ (1978) The effects of arteriovenous shunts on cardiac function in renal dialysis patients-an echocardiographic evaluation. Clin Nephrol 9: 205-209. [Crossref]

11. Jin H, Alfonso L, Singh A, Migdal S, Spears JR (2006) Case report: recurrent heart failure with preserved ejection fraction but markedly elevated BNP in a51-year-old female on hemodialysis with oversized AV fistula. Int J Cardiol 110: 429-430. [Crossref]

12. Young PR Jr, Rohe MS, Marterre WF Jr (1998) High-output cardiac failure: two cases. Am J Surg 64: 239-241. [Crossref]

13. Schneditz D, Roob J, Oswald M, Pogglitsch H, Moser M, et al. (1992) Nature and rate of vascular refilling during hemodialysis and ultrafiltration. Kidney Int 42: 1425-1433. [Crossref]

14. Basile C, Casino F, Lopez T (1990) Percent reduction in blood urea concentration during dialysis estimates $\mathrm{Kt} / \mathrm{V}$ in a simple and accurate way. Am J Kidney Dis 15: 40-45. [Crossref]

15. Owen WF Jr, Lew NL, Liu Y, Lowrie EG, Lazarus JM (1993) The urea reduction ratio and serum albumin concentration as predictors of mortality in patients undergoing hemodialysis. N Engl J Med 329: 1001-1006. [Crossref]

16. Trubel W, Staudacher M, Magometschnigg H, Wolner E (1994) The false aneurysm after iatrogenic arterial puncture: incidence, risk factors, and surgical treatment. Int $J$ Angiol 3: 1061-1071.

17. Miller GA, Goel N, Friedman A, Khariton A, Jotwani MC, et al. (2010) The MILLER banding procedure is an effective method for treating dialysis-associated steal syndrome. Kidney Int 4: 359-366. [croosref]

18. Rajan DK, Bunston S, Misra S, Pinto R, Lok CE (2004) Dysfunctional autogenous hemodialysis fistulas: outcomes after angioplasty--are there clinical predictors of patency? Radiology 232: 508-515. [Crossref]

19. Badero OJ, Salifu MO, Wasse H, Work J (2008) Frequency of swinging segment stenosis in referred dialysis patients with angiographically documented lesions. $\mathrm{Am} \mathrm{J}$ Kidney Dis 51: 93-98. [Crossref]

20. Turmel-Rodrigues L, Pengloan J, Rodrigues H, Brillet G, Lataste A, et al. (2000) Treatment of failed native arteriovenous fistulae for hemodialysis by interventional radiology. Kidney Int 57: 1124-1140. [Crossref]

21. Nam DH, Kim YK, Goo DE (2008) Percutaneous angioplasty in a cephalic arch stenosis of native arteriovenous fistula (abstract). J Vasc Interv Radiol 19: S36.

22. Rajan DK, Clark TW, Patel NK, Stavropoulos SW, Simons ME (2003) Prevalence and treatment of cephalic arch stenosis in dysfunctional autogenous hemodialysis fistulas. $J$ Vasc Interv Radiol 14: 567-573. [Crossref] 
Magbri A (2018) Bigger is not always better: The consequences of High-flow hemodialysis arterial-venous fistula (Mega fistula)

23. Jaberi A, Schwartz D, Marticorena R, Dacouris N, Prabhudesai V, et al. (2007) Risk factors for the development of cephalic arch stenosis. $J$ Vasc Access 8: 287-295. [Crossref]

24. Pasklinsky G, Meisner RJ, Labropoulos N, Leon L, Gasparis AP, et al. (2011) Management of true aneurysms of hemodialysis access fistulas. J Vasc Surg 53: 12911297. [Crossref]
25. Schillinger F, Schillinger D, Montagnac R, Milcent T (1991) Post catheterization vein stenosis in hemodialysis: comparative angiographic study of 50 subclavian and 50 internal jugular accesses. Nephrol Dial Transplant 6: 722-724. [Crossref]

26. Schwab SJ, Quarles LD, Middleton JP, Cohan RH, Saeed M, et al. (1988) Hemodialysisassociated subclavian vein stenosis. Kidney Int 33: 1156-1159. [Crossref]

Copyright: $@ 2018$ Magbri A. This is an open-access article distributed under the terms of the Creative Commons Attribution License, which permits unrestricted use, distribution, and reproduction in any medium, provided the original author and source are credited. 